\title{
Brúnkahk Tek: \\ An Extinct Language
}

\section{Damaris Castro ${ }^{2}$}

\section{Universidad Nacional, Costa Rica}

\section{RESUMEN}

En Costa Rica hay seis lenguas indígenas reconocidas oficialmente. Cada una de ellas disfruta de una condición diferente en cuanto a sus tradiciones y números de hablantes, entre otras. A pesar de los esfuerzos del gobierno de Costa Rica y otros investigadores desde 1995, las lenguas han enfrentado dificultades a nivel interno y externo, las cuales han resultado en el debilitamiento o inclusive pérdida de las mismas. Esto nos lleva al caso de boruca, una de las lenguas de Costa Rica que puede ahora ser considerada una lengua extinta. Este artículo presenta una descripción general del pueblo boruca, sus tradiciones y sus principales características, y a la vez of rece al lector una descripción tipológica general de la lengua en la cual se discuten brevemente los rasgos generales de su gramática.

\begin{abstract}
In Costa Rica there are six officially recognized indigenous languages. Each enjoys a different condition in terms of its traditions and number of speakers, among others. Despite efforts of the Costa Rican government and other researchers since 1995, the languages have met endogenous and exogenous difficulties that have resulted in the weakening and even loss of the languages. This leads us to what happened to Boruca, one of the indigenous languages of Costa Rica which can now be considered an extinct language.
\end{abstract}

P'aper presented at the I Simposio del Programa Lenguas Indígenas de la Baja Centroamérica (I'ROLIBCA), September 2007, Universidad Nacional, Heredia, Costa Rica.

I:-mail: dcastro@una.ac.cr 
This article presents a general description of the Boruca people, their traditions and main characteristics, and it also introduces the reader to a general typological description of the language where the main features of its grammar are briefly discussed.

Palabras clave: boruca, lenguas indígenas, sociolingüística, lenguas extintas, tipología.

Key words: Boruca, indigenous languages, sociolinguistics, extinct languages, typology.

Only recently have the indigenous languages of Costa Rica been studied greater in depth. Although there has always been a relative interest in these languages, acknowledged through the implementation of projects and academic studies, only a few of these studies and projects have resulted in material that could actually be of use in the true preservation of these languages. This takes us to the case of Boruca or Brunkahk tek, ${ }^{3}$ which has not been able to survive the change and pressure of both exogenous and endogenous aspects. The Boruca indigenous group is located in the south of Costa Rica, in the province of Puntarenas, specifically in the area of Buenos Aires. The people are divided mainly into two reserves: Boruca and Curré. The language once spoken by the Boruca people is now considered a dead language, despite the effort and interest of linguists and other researchers. Nevertheless, the current study aims at collecting information that is still accessible and documents important aspects of the language and culture that are still available. A description of the town and the people is presented in this first section. In addition, a brief typological description is provided to illustrate linguistic generalities

$\overline{3}$ Traditionally, a Spanish alphabet has been used in various Boruca texts (see Adolfo Constenla y Espíritu Santo Maroto, Leyendas y tradiciones borucas (San José: Editorial Universidad de Costa Rica, 1986); and Miguel A. Quesada Pacheco, Hablemos boruca: (Chá dindi' tégat tegrá) (San José: Ministerio de Educación Pública, Departamento de Educación Indígena, 1995). Alternatively, an English-based alphabet will be used in this and future texts, mainly considering the fact that this text is written in English. 
of Boruca. As the study advances, more references will be made towards the analysis of Boruca and its linguistic characteristics.

\section{Background information}

Despite the difficult access to the reserve during the rainy season, many changes have reached the town of Boruca. With the growth in population, urbanization is clearly evident in the area, also giving way to a more modern infrastructure, different from that observed there in the past. A series of governmental urbanization projects have resulted in the proliferation of cement houses, offering the comfort that people enjoy in other communities throughout the country: zinc roofs, indoor bathrooms, running water, electricity, etc. Only a few ranchos can still be found around the Boruca community. Some families like to have one by their houses so that they can enjoy them during the hot months. One in particular stands out: that found where the Museo Comunitario Indigena de Boruca is located. The architecture of this Museum offers a quick glance at the past by showing how the living facilities used to be years ago. There, the proud Borucas exhibit their artcrafts as a way of showing the visitors that some of their traditions and customs are still alive today. Unlike the language, the traditional crafts are still present in the community and they enjoy a healthy status.

In fact, the most important economic activity of the Borucas is related to their artcrafts. The Borucas consider themselves (and are also considered by outsiders) very skillful artists. They are very proud of their craftsmanship and many make a decent living out of it. Sometimes, entire families work together to create souvenirs that are later sold to visitors, sent to San Jose or distributed among some of the resorts in the area. Women, mainly, make hand-woven products: bags, purses, hats, belts and others. In some cases, natural cotton is processed and dyed naturally to create products of higher quality. In most cases, other types of textiles are used to keep up with the number of 
orders that are placed. Men, on the other hand, work the wood. They create wooden masks and other wooden products that are also sold in the national market. When asked about the main occupation for the people in the town, one Boruca woman said, "We make crafts, we are famous for that, and our designs are unique." Then she added, "Well, some other people also work in education and older people work the land." This last statement is as evident in the landscape as it is in the diet. The landscape around the reserve exhibits agricultural fields, some scattered in between the houses while others are hidden up in the mountains. Many of the families grow most of the products that they consume such as beans and corn, along with many of the traditional roots that are common in their diet, such as cassava, cocoyam and sweet potato. This diet, it should be noted, is more appreciated by the older generations. Younger generations very much enjoy the products that they can find in the nearby store: sodas, juices, chips and all sorts of snacks and convenience food.

The Borucas, in areas other than the ones related to their language, have traditionally been thought of as fierce fighters against change. Historically, they were considered brave opponents to Spanish conquest. During this time, they wore masks representing evil spirits. While using these masks, they ambushed the Spanish who traveled their roads. This practice is still represented today every December $31^{\text {st }}$ in their Fiesta de los Diablitos ('Festival of the Little Devils"), in which they celebrate "their belief in the mythological god Tatica Kuasran and his son Sancrawa." Interestingly, this tradition, along with their famous artcrafts are the few things which are still present today. As mentioned above, the language never enjoyed this status. Several attempts have been made to preserve the language, one of which took place in 1982, when the community received the donation of a broadcasting station, later "Radio Cultural Boruca." This was done with the idea of broadcasting programs that used Boruca

4 Kan Tan Project, Costa Rica. <http://www.workingabroad.com/page/30/kan-tan-costa-rica.htm>. Retrieved May 14, 2007. 
in their contents which could have helped preserve the language. This attempt also failed. Currently, the radio station only broadcasts programs in Spanish. Several religious programs, Mexican music, local activities (fairs and karaoke competitions), educational programs and other music are also aired.

\section{Demographics and others}

As mentioned above, the Boruca indigenous group is located in the south of Costa Rica, in Buenos Aires, Puntarenas. The people are divided mainly into two reserves: Boruca and Curré. In contrast to what happened to other indigenous groups in the country, this group still remains in the original territories that they occupied before colonial times. They were not moved to other lands, as were the Bribris, for example. According to Solano (2000), ${ }^{5}$ currently, the Boruca population adds up to 2017 inhabitants; 1386 live in Boruca and 631 live in Curré (the total population amounts to 3936 including the nonindigenous people living on the reserve). One interesting point is that on the Boruca reserves, $48.8 \%$ of the people living there do not have indigenous ancestry; that is, many "outsiders" are now part of the communities. This open, close relationship with people from outside groups is the one to blame, according to some Borucas, for the loss of their mother tongue. They say that they have always been friendly and open to outsiders. Although they feel that throughout history they were somehow marginalized by white people, they say that they do not think that that is important now, because they feel they are what they want to be. The family dynamics are clearly marked by a patriarchal relation. Men are more respected than women and have the final say in family matters. Marriage is not the only type of relation that is observed. Couples decide whether they want to get married officially or if they prefer to live together before getting married. In terms of

5 Centro Centroamericano de Población. <http://www.ccp.ucr.ac.cr/noticias/simposio/paf/solano.pdf>. Retrieved May 14, 2007. 


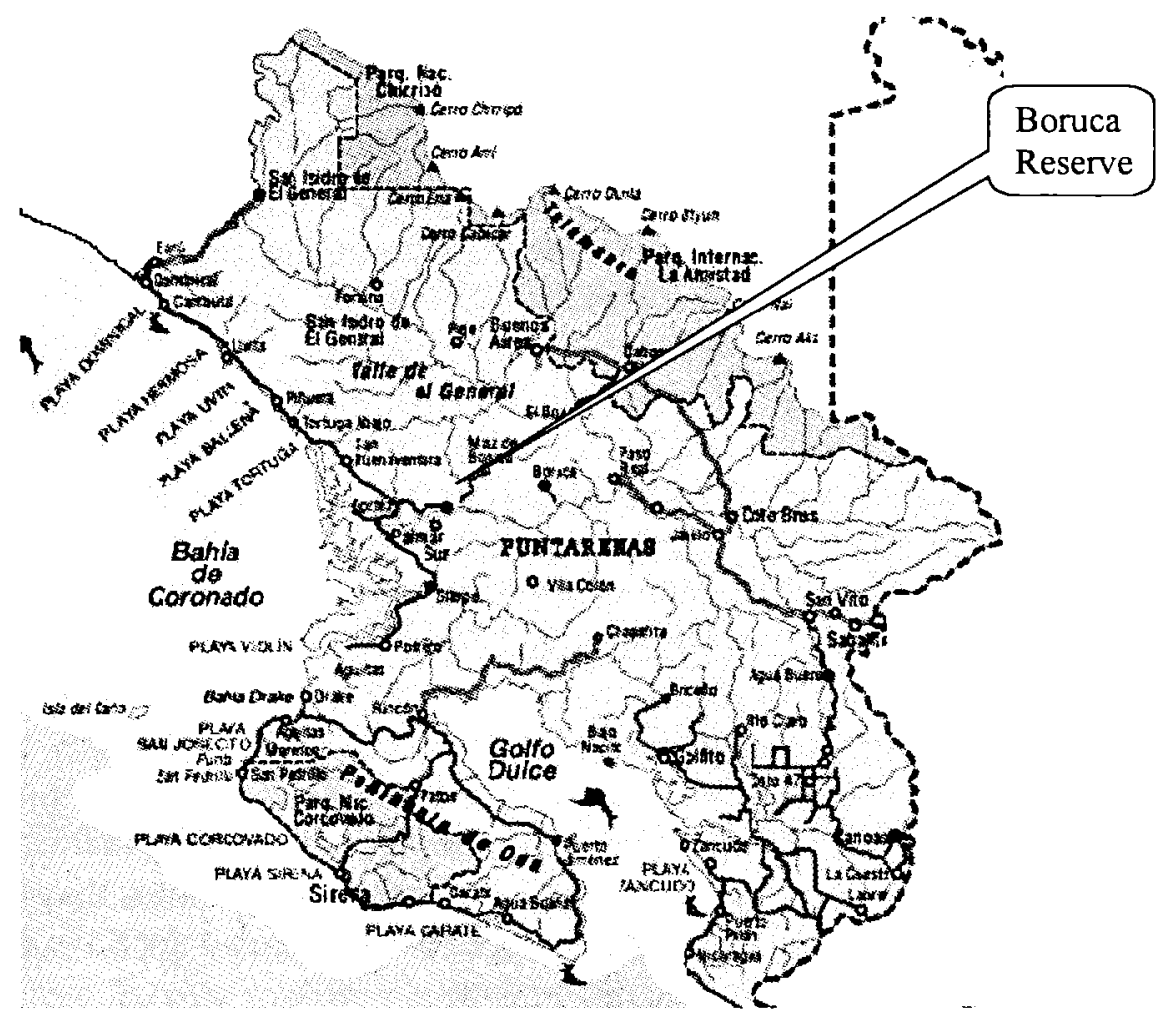

Figure 1. Geographic location of the Boruca Reserve in the southern Pacific of Costa Rica. Adapted from: <http:// www.costaricamap.com/ing/map4.html >. Retrieved August 3, 2007.

religion, most people are catholic. The local church offers mass regularly during the weekends and special festivities. Some people attend protestant services, but most of the population is still catholic. There is no evidence of original Boruca religious practices. The oldest Boruca semi-speakers say that they have always been catholic. 


\section{Genetic affiliation of the language}

Boruca is a Chibchan language. The original territory of this family was the present-day Costa Rican-Panama border zone, along the Talamanca mountain range. Due to north and southbound migratory movements this territory has expanded (Constenla, 1991 and Fonseca and Cooke, 1993), ${ }^{6}$ although, not affecting the Boruca original location. According to J. Diego Quesada, ${ }^{7}$ the Chibchan family is a large language family now distributed along the countries of Honduras, Nicaragua, most of Costa Rica, and areas of Panamá, Colombia and Venezuela. The Chibchan family is divided into the Paya and the Southern languages. The latter are split into the Pota, Isthmian and Magdalenian languages. The Boruca language comes from the Isthmian branch and, like Teribe and Cuna, has no immediate sister languages. The other members of the Isthmian branch are the Bribri and Cabécar (in the Viceita branch), the Guaymí and Bocotá (in the Guaymian branch) and the deceased Chánguena and Dorasque (in the Doracic branch). Except for the Cunas and the members of the Doracic branch, the rest of the languages are spoken in Costa Rican territory (plus the Guatuso, from the Pota group). ${ }^{8}$

\section{Previous research}

There is a variety of literature pertinent to Boruca, its language and culture. It basically consists of a few descriptive studies related to linguistic aspects of the language and a series of compilations of narrative works. Espíritu Santo Maroto, a native speaker of the language figures as a self-taught linguist. His effort to maintain and

Adolfo Constenla, Las lenguas del Área Intermedia (San José: Editorial Universidad de Costa Rica, 1991): Oscar Fonseca and Richard Cooke, "El sur de América Central: contribución al estudio de la región histórica chibcha", Robert Carmack (ed). Historia General de Centroamérica (Madrid: FLACSO. 1993. Vol. 1): 217-282.

7 J. Diego Quesada, The Chibchan Languages (Cartago: Editorial Tecnológica de Costa Rica, 2007).

8 For further, detailed information, see Quesada (2007). 
strengthen the language is worth mentioning. He struggled to keep the language alive through his constant compilation of grammatical aspects and traditional legends of Boruca, written both in Spanish and Boruca resulting in the publication of a book. ${ }^{9}$ He dedicated his time and effort to teach the language to younger generations and was always willing to contribute in any aspect related to the language. He also served as an informant to those linguists and other researchers interested in Boruca, as in the case of Constenla, who also has contributed to the preservation of the language and culture through his publication Leyendas y Tradiciones Borucas, ${ }^{10}$ as part of the field research done by the University of Costa Rica (UCR). This text offers an introduction to phonological and grammatical aspects of the language as well as references to the orthographic system. The second section pertains to a historical background in relation to the legends that later follow, and their corresponding Spanish translation. A short section offers a Boruca-Spanish, Spanish-Boruca vocabulary used throughout the legends and a set of legends, in Spanish-only, is presented towards the end of the book.

Furthermore, one of the linguists who has probably worked the most with this language is Quesada Pacheco, a non-native, fluent Boruca speaker himself. In 1995, he published a small book that offers a compact course of Boruca. ${ }^{11}$ This book provides those interested in learning the language with a straightforward course, which covers the basic aspects of its grammar and also contains exercises to test the students' knowledge. Following a clear division of areas of study, the book could be used as a very helpful tool in language classes. Quesada ${ }^{12}$ and Quesada Pacheco also did a linguistic analysis of the particle $k i$ (qui) and its various uses in Boruca. Moreover, he worked

9 Espíritu Santo Maroto Rojas, Lengua o dialecto boruca. Miguel Quesada Pacheco, ed. (San José, Editorial Universidad de Costa Rica, 1999).

10 Constenla and Maroto.

11 Quesada Pacheco, Hablemos Boruca.

12 J. Diego Quesada and Miguel A. Quesada Pacheco, "Boruca ki: de definido a específico y la hipótesis de las funciones contiguas". Estudios de Lingüistica Chibcha, 14 (1995): 89-99. 
on the compilation of Boruca legends in his Narraciones Borucas, ${ }^{13}$ where he presents background information on the town and its people, a set of legends, a section of Spanish narrated legends, a section on manuscripts from Espíritu Santo Maroto, a literal translation of the Boruca texts referred to earlier in his text, and a set of pictures. Additionally, he wrote an article on adjective use, ${ }^{14}$ and together with Rojas, he also published a Boruca-Spanish/Spanish-Boruca dictionary. ${ }^{15}$ Finally, the last and most recent group of linguistic work has been done by Quesada. He has published several articles that examine different aspects of the language. He has covered different topics varying from topicality ${ }^{16}$ to subject coding ${ }^{17}$ and grammaticalization ${ }^{18}$ among others. In his article, Adiós Boruca, Sibú ki ba wi? ra moreng, ${ }^{19}$ he offers a detailed description of all the Boruca related literature as well as a classification of it according to the type of document, whether it is linguistic, literary or other. Some of this literature will be used in the on-going research due to the above-mentioned state of the language. Since there are not many informants still available to conduct linguistic research, some of the already existing material can be of great help in analyzing and studying the language, given that it represents the oral information that can be retrieved only partially from today's surviving semi-speakers of the language.

$\overline{13}$ Miguel A. Quesada Pacheco, Shán rojc brúncajc rójc: Narraciones borucas (San José: Editorial Universidad de Costa Rica, 1996).

14 Miguel A. Quesada Pacheco, "El adjetivo boruca". Estudios de Lingiuística Chibcha, 16-17 (19971998): $157-165$.

15 Miguel A. Quesada Pacheco and Carmen Rojas, Diccionario Boruca-Español, Español-Boruca (San José: Editorial de la Universidad de Costa Rica, 1999).

16 J. Diego Quesada, "Topicalidad y enfoque en boruca: el caso de ang." Estudios de Lingiuística Chibcha, 15 (1996): 43-58.

17 J. Diego Quesada, "En Route to Subject-Coding: Evidence from Boruca". Theoretical Linguistics 27 (2001): 55-86.

18 J. Diego Quesada. "The Grammaticalization of SPECIFICITY (and Beyond) in Boruca". International Joumal of American Linguistics (IJAL) 66 (3) (2000): 549.562.

19 J. Diego Quesada, "Adiós boruca: Sibli ki ba wì ra moréng... "Estudios de Lingüística Chibcha, 2021 (2001-2): 55-64. 


\section{Sociolinguistic situation}

As mentioned above, Boruca is a dead language. The last native speaker of the language died in 2003, thus allowing the language to reach the highest point in its obvious decay and giving way to its imminent death. Currently there are only three semi-speakers of the language. These elder, semi-speakers grew up having a somewhat strong contact with the language; this contact was not strong enough though for this language to be their first and most important means of oral communication. These three semi-speakers are: Don Nemesio González (age 82), Doña Eligia Maroto (age 75) ${ }^{20}$ and Doña Angela González (74), whom, according to the former two, "does not speak the language correctly." In the particular case of Don Nemesio and Doña Eligia, they had managed to keep the language more alive thanks to their marriage, because it gave them the chance to practice the language with relative ease and frequency. Although there are many people in the community who claim to partially understand the language, they are not able to produce sentences or even phrases. Spanish is, by far, the language of choice for people in the community. There seems to be a sense of shame towards the Boruca language. Situations are opposing and even contradictory sometimes. There are Boruca classes in the elementary school, and people say it is "somewhat sad" that the language is not spoken anymore, but clearly people do not appreciate the language enough to make a real effort to maintain it. With a big smile on his face, Don Nemesio recalls how, whenever his teacher caught him speaking Boruca, the teacher would chase him and hit him, to the point that Don Nemesio had to jump out the classroom window to escape from the punishment. Now, students are given the chance to learn the language but they try to "escape" from this situation.

20) At the time of this writing Doña Eligia was alive; sadly, she passed away on August $21^{\mathrm{st}}, 2007$. 
The term "semi-speaker" has been used so far to describe the last surviving speakers of Boruca. For Quesada, ${ }^{21}$ a semi-speaker is defined as an individual who shows "an imperfect command of the language because it was not the first and more/most important language in early infancy." Looking back at the anecdote described above we can conclude that although Boruca started out as an important language in the semi-speakers' repertoire, they had to resort to Spanish due to imposition of their Spanish-speaking teachers they had. According to Fasold, "language death occurs when a community shifts to a new language totally so that the old language is not longer used."22 This explains what happened to Boruca, where the speakers of the language limited their use of Boruca and, instead, used Spanish more and more, to the point that Boruca was no longer spoken at all. This same author mentions a few causes for language shift (which eventually leads to language death); one of them being "school language and other governmental pressures," which can be reflected "in the larger proportions of older speakers using the declining language [more] than younger speakers." This gives way to the type of death that Boruca underwent. Quesada, following Campbell \& Muntzel, ${ }^{23}$ characterizes this death as a radical death, ${ }^{24}$ one that is achieved once "the speakers stop using their language as a means of self defense," like was evidently the case of the Boruca speakers. For Quesada, radical death involves language shift and death occurring within one or two generations at the most, which means that there is not enough time for the speakers to experience reduction in the input, but rather that there is simply a reduction in the output by the generation still

21 J. Diego Quesada, “Synopsis of a Boruca terminal speaker”. Amerindia 25 2000: 65-86.

22 Ralph Fasold, The Sociolinguistics of Society (New York: Basil Blackwell, 1984) 213-217.

23 L. Campbell and M. Muntzel, "The Structural Consequences of Language Death." Dorian (ed.) (1989) 181-196.

24 The other types of death are sudden death, in which all speakers suddenly die or are killed; gradual death, a process in which the speakers start by shifting to the other language and the next generations have little to no proficiency in the language; and finally bottom-to-top death where the language is lost in the family context but it still used in ritual ceremonies. 
using it. This is why the remaining speakers of the language are highly competent but the younger generations are not since they did not have the exposure to the language that they would have required to achieve linguistic competence.

The state of Boruca can also be illustrated following Bauman ${ }^{25}$ where the following categories of classification (originally used for indigenous languages in the United States) are given: 1. flourishing, 2. enduring, 3. declining, 4 . obsolescent, and 5. extinct. The values given below in parenthesis result from personal observation on the reserve and following these values, Boruca obviously falls under the categorization of extinct, since the values are negative all across the elements evaluated. Thus, there are several elements to be considered in this classification: age of the speakers and their corresponding degree of bilingualism (-), proportion of speakers in relation to the total population (-), fluency of young speakers (-), degree of preference for the native language (-), degree of bilingualism (-), and finally, adaptation capacity of the native language to a changing culture (-). Most elements are clearly absent in the reserve; i.e., only a few elders in the community speak the languages, but younger generations are not fluent in the language and they simply do not speak it. Younger generations prefer Spanish to Boruca and the mainstream Costa Rican culture has pretty much absorbed the Boruca culture; the proportion of (semi)-speakers is of $0.03 \%$ in relation to the total population. In the end, this classification leads to the same idea presented throughout the paper: Boruca is an extinct language.

The effect of the contact relation between Spanish and Boruca is clear, as is the attitude of the Borucas towards their former language. Boruca has not played a main role in oral or written communication for some time now; and that does not seem to represent a problem for the Borucas. They feel it is normal for everybody there to

25 James Bauman, .4 Guide to Issues in Indian Language Retention (Washington: Center for Applied Linguistics, 1980). 
speak Spanish and that they really do not need Boruca to succeed in any field. Interestingly enough, what is new now is the fact that the language has been given a new function: the Boruca language has reached a state of secret code. Don Nemesio and Doña Eligia say that they know there are people in their community who understand the language, so they use it with these people when they do not want others to know what they are saying. When asked to describe the situations in which they use the language, she does not hesitate to say that they use it when they wish to avoid being understood by others. She recalls a recent situation where they saw a man trying to pickpocket a lady friend from the community and by using Boruca she warned the victim, who quickly moved away, thus avoiding the mugger. While being on the reserve, I experienced this use of the language by the younger generations who used the language to name actions/objects such as: shua'kú' ('defecate') or shua'kú'kra ('latrine'). On various occasions, people in the community referred to me as the si'kua (foreigner/white), when they were talking about me and did not want me to know, although many times the context would have given them away, even if I did not know the meaning of the word. These and other words are used in Boruca when outsiders are present and they want to stop them from understanding what they are saying. The grandchild of Don Nemesio and Doña Eligia uses the former when he needs to go to the bathroom while in play school, and he does not want his classmates to understand what he needs. This could be taken as an indication that not all children retain or know certain words, but the ones who do, use them as a code. We are not simply dealing with taboo words here. There are several other words that are used in the community within various contexts.

Although, as mentioned earlier, there are Boruca language classes in the elementary school, this has not been enough for children to create strong ties with the language and they still prefer to speak Spanish at all times. Besides, students receive Boruca classes in elementary school and once they move on to high school, they do not have 
access to these language lessons anymore. The pressure is now stronger towards learning English in the community. The Board of Education is trying to implement indigenous language programs, particularly in the indigenous reserves, but it still promotes English (and French to some extent) in both primary and secondary schools throughout the country. Given the number of tourists who visit the reserve and the fact that the crafts are acquired mainly by tourists, Borucas think that it will bring them a lot more benefits to learn English. In summary, there are various aspects that have come together and which have resulted in the death of the language. In the following section, a typological description of the language will be presented so that the reader can become somewhat familiar with a language that will soon stop being heard in one of the indigenous communities in Costa Rica.

\section{Typological characterization}

The basic word order in Boruca is SOV, as shown in (1); SV order, can be observed in intransitive sentences (2). Boruca also allows for other orders in cases where emphasis or focus is given to a particular element, which is then placed in sentence initial position as shown in (3b), which is the focussed version of (3a). There are also cases in which the basic word order is altered when the object is new and the subject is given; the subject then can be post verbal, thus giving way to an OV structure, with argument (object) focus (4).
(1) $\begin{array}{lll}D i & \text { róhk } & k i \\ 1 \mathrm{PL} & \mathrm{PL} & \mathrm{EMPH}\end{array}$
'We have a little dog
aúh
xít
$k i$
bag-rá
(2) Di-ng deg-rá Rédi íh
1PL.EMPH go-PrS San José to
'We go to San José'



(3a) At
ki bihg-rá
dué'shi
1sG EMPH getup-PRS early
'I get up early'
(3b) Dué'shi a-ng bihg-rá
early 1sG-EMPH getup-PRS
'Early, I get up'
(4) Jose ki shés-kr-i-ng
jose EMPH (OBJ) kick-pst-3sG-EMPH
'She kicked Jose'

Boruca has a long set of postpositions, both simple and compound. These are used to express semantic roles such as dative (5), locative (6), and associative (7).
$\begin{array}{llll}\text { (5) } & \text { be } & k i & k a \\ \text { 3sG } & \text { mother } & \text { EMPH } & \text { for }\end{array}$ 'For your mother'

(6) Di' duahgí

river on the other side

'On the other side of the river'
(7) I ki kahwi'-íra si'kua e'dé 3sG EMPH live.IPRV foreigner with He lived with a foreigner'

Some examples of compound postpositions are káhk ta ('inside in'), yrá ka ('on top of'), and cheng tá ('behind'). In his list of postpositions Quesada Pacheco (1995) ${ }^{26}$ includes a set of markers of

$\overline{26}$ Miguel A. Quesada Pacheco, Hablemos boruca. 
various other functions which hardly conform to the postposition profile or prototype. Such cases include at ('in the shape of'), ihchí ('like, that looks like'), do' 'sh ('similar to, same as, like') and others. For an element to be considered an adposition (particularly 'a postposition' in the discussion that attains us), it has to be a free morpheme which governs a noun phrase and which provides information pertaining location, position or direction; but not form, as in Quesada Pacheco's examples. Usually, when classifying such morphemes, morphological, syntactic and semantic criteria are followed. Although the above mentioned elements conform to the morphological and syntactic criteria that is, they are "particles...that say something about the semantic role of an adjacent noun phrase in the clause..."27 and they also occupy a specific syntactic position (post nominal) they do not conform with the semantic criterion since they do not provide information concerning location, direction or position. Conversely, as mentioned above, they seem to express other meanings, such as shape, and thus cannot be considered postpositions. To illustrate one case, let us take that of dó'sh given above, for which Quesada Pacheco uses the example: nong do'sh 'like a monkey'; that phrase fulfills a clearly adverbial function, but does not meet the criteria for a postposition.

In the nominal phrase, the nouns are followed by the modifiers (i.e., adjectives) (8). Furthermore, Boruca also exhibits a plural marker $\operatorname{rohk}^{28}(8),(9)$, which marks both adjectives and nouns. Boruca is the only Chibchan language that exhibits the presence of an article: $k i,{ }^{29}$ which is postnominal (10).

(8) abí moréng

person nice

'nice person'

27 Thomas E Payne, Describing Morphosyntax: A Guide for Field Linguistics (Cambridge: Cambridge University Press, 1997) 86.

28 Rohk can also mark verbal and adjectival plurality.

$29 K i$ also has other functions in Boruca, some of which are discussed below. 
(9) abi róhk moreng rohk

man $\mathrm{PL}$ nice $\mathrm{PL}$

'nice men'

(10) srut xít ki

flower DIM ART

'The little flower'

In Boruca, the demonstrative adjectives hwe' ('this, these') and chi' ('that, those') precede the nouns (11). Other markers such as rohk or $k i$ (as mentioned above) follow the noun in this construction. The demonstrative pronouns $h w a ́$ ('this, these') and yá ('that, those') are followed by the particle $k i$; they can also function as pronouns in which case they can be determined by $k i(12)$.
(11) Ué kúp róhk ki moreng rohk i-rá DEM egg PL EMPH good PL COP-PAST 'These eggs were good'
(12) Uá ki yá ka'yéng-ra Raquel
DEM EMPH REFL call-PRST raquel
'This (one) is called Raquel'

The possessive markers are used prenominally to express possessive determination, although technically they are not determiners. These possessive markers undergo a series of phonological changes depending on their environment. For example, for the first person singular the different allophones are at (13), ad (14), and $a^{\prime} r$ (15).
(13) at xasúh
1sG grandfather
'My grandfather' 
(14) ad bríshba

1sG grandson

'My grandson'

$\begin{array}{lll}\text { (15) } a \text { 'r } \quad u & k i \\ 1 \text { sG house } & \text { EMPH } \\ \text { 'My house' } & \end{array}$

The relation of possession follows the order possessor-possessed (16). Alternatively, when the possessor is a proper name, a personalization or an animal, then the possessives $i$ or ígui are placed between the possessor and the possessum (17).

(16) chubú kráng

cotton plant

'Cotton plant'

(17) Juan ígui ú

Juan poss house

'Juan's house'

As for the expression of negation, there is one negative marker in Boruca, the suffix $i$ 'shi, whose position is between the stem and the $\mathrm{TAM}^{30}$ markers present or future (18), imperfect (19), perfect (20), and pluperfect (21). Quesada Pacheco ${ }^{31}$ proposes a different negative marker for each one of the TAM categories; whether he does this to facilitate the learning or understanding of the different verbal tenses ${ }^{32}$ or due to an erroneous analysis of the data is not clear. However, the analysis of the data presented in his texts shows that $i$ 'shi is the only negative marker of the language and it presents phonologically conditioned

TAM stands for Time, Aspect, Mood.

Quesada Pacheco (1995) 37, 60, 64, 73.

His sketch of Boruca structures is clearly pedagogically oriented.

68 
variants. I'shi is placed between the stem of the verb and the tense marker; and the various phonological changes seem to be triggered by the environment. These changes will be discussed in future papers; for now it will only be argued that they could involve epenthesis (vowel insertion) or consonant deletion.

\section{(18) I ki deg-ísh-á \\ 3sG EMPH go-NEG-PRS/FUT \\ 'He doesn't go'}

(19) At ki deg-ísh-irá

1sG EMPH go-NEG-PST

'I didn't go'

(20) $I \quad k i \quad$ deg-ísh-irá

1 sG EMPH go-NEG-PST

'He didn't go'

(21) $\mathrm{Di}$ rohk $k i \quad$ deg-i'shi-kírá

$1 \mathrm{PL} \quad \mathrm{PL}$ EMPH gO-NEG-PRV

'We hadn't gone'

Regarding grammatical relations, Boruca, like many other languages in this family, follows the nominative-accusative pattern. In this type of pattern, elements are grouped in such a way that the Subject (S) and the Agent (A) are treated the same while the Patient (P) is treated differently. These relations will be exemplified below; let us just say for now that in Boruca there are markers that can be used for nominal subjects or agents but not with nominal phrases in the object position, or they are restricted to certain nominals in this function.

The grammatical relations of subject, direct object and oblique can be identified in Boruca. Thus far, no syntactic evidence has been found for the existence of an indirect object, although there seems to 
be some syntactic constructions that point to the existence of this category. The mainstream linguistic literature agrees on the fact that the existence of the above-mentioned categories can be determined through coding properties (morphology) or through behavioral properties (syntax); for each relation there are certain tests that can be applied.

Although Boruca does not have a system of agreement between the subject and the verb, it is still possible to isolate the subject noun phrase in opposition to other pronominal noun phrases. For example (22)-(25) below illustrate how the morpheme ang can only be used with noun phrases (both nominal and pronominal) in subject but not object function while the morpheme $k i$ can be used with nominal and pronominal noun phrases in subject position and with nominals but not pronominals in object position.

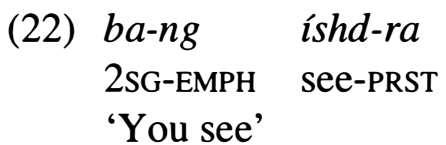

(23) *Luis ki ba-ng báht-kra

Luis EMPH you-EMPH hit-PST

'Luis hit you'

(24) $D i$ 'rohk $k i \quad d i$ ú $k i$ ishd-ra

$1 \mathrm{PL}$ PL EMPH lPL.POSS house EMPH see-PRST

'They see their house'
(25) $* B a \quad k i$
báht-kr-i-ng
2sG EMPH (OBJ) hit-PST-3sG-EMPH
'He hit you'

In Boruca, the grammatical relation of subject can also be identified syntactically, concretely in terms of syntactic processes 
requiring the existence of this category; such cases include two verb clauses (26), (27), and (28a, b). In the cases of (26)-(28), there are two verbs that have the same subject referent; the second subject can be omitted due to this co-referentiality since it is the same NP which controls both verbs. In the particular cases of $(28 a, b)$, we see that the overt subject of the sentence can be omitted as long as we have the appropriate marking on the first verb. All of these cases show subject identity in the second clause.

(26) $\mathrm{Ba}$ ki ya-kra di' ta; ya'

2SG EMPH go-PST river to; REFL

yo'kr-bang

bathe-PST-2sG-EMPH

'You went to the river; (you) bathed'

(27)

Éxe Abí sabúk di-ng mang i-rá

one person Panamanian 1PL-EMPH with COP-PRS

cab-íshi-krá

sleep-NEG-PST

'One Panamanian person who was with us did not sleep'

(28a) I ki yá' sa'-krá dí yang bík

3SG EMPH REFL start-PST water drink yesterday

'He started to drink water yesterday'

(28b) yá' sa'-krá-i-ng dí yang bík

REFL start-PST-3SG-EMPH water drink yesterday

'(He) started to drink water yesterday'

Coordinated sentences are also helpful in showing the grammatical relation of the subject. Thus, (29) shows the coordination of a transitive and an intransitive sentence; in these, the second subject could be either the subject or the object of the first sentence, the correct 
relation is only determined through the corresponding marking on the second verb.

(29a) at ki ramrohk ki isht-krá ine

$1 \mathrm{SG}$ EMPH woman DEF see- PST and

shit-kr-a-ng

laugh-PST-1 SG-EMPH

'I saw the woman and I laughed'

(29b) at $\quad k i \quad$ ramrohk $\quad k i \quad$ isht-krá ine

$1 \mathrm{sG}$ EMPH woman DEF see-PST and

shit-kr-i-ng

laugh-PST-3sG-EMPH

'I saw the woman and she laughed'

Finally, an intransitive sentence (a one-argument sentence) requires the category subject for the sentence to be grammatical.

\section{(30) Juan ki tru'k-ra \\ Juan EMPH fall-PST \\ 'Juan fell'}

The grammatical relation of object in Boruca can be identified syntactically as well; it is the NP that immediately precedes the verb; the object and the verb form a cohesive unit. This is observed in transitive sentences in which the subject appears clearly marked postverbally and the object is the NP that precedes the verb (31).
(31) Anna ki
báht-kr-i-ng
anna EMPH (OBJ) hit-PST-3sG-EMPH
'He hit Anna' 
(32) illustrates the case of a verb that, semantically, requires two arguments. The first NP observed represents the subject of the sentence, while the second NP, the one immediately preceding the verb, represents the object.

$\begin{array}{llllll}\text { (32) Át } & k i & y a-k r a ́ & \text { muá } & \text { rohk } & d i ́ \\ \text { 1SG } & \text { EMPH } & \text { go-PST } & \text { plantain } & \text { PL } & \text { look for } \\ \text { 'I went to look for plantains' } & \end{array}$

Oblique grammatical relations in Boruca include datives (33), locatives such as duahgí ('on the other side') and cába ('where'), as (34) and (35); and instrumental e'dé (with) (36).

(33) Yá ta i-ng suá ki shúng-rá rohk

DEM in 3sG-EMPH shrimp EMPH sent-PST PL $i$ be ki yet

3sG mother EMPH for

'She sent shrimp for her mother'

(34) At ki cab-krá dí duahguí

$1 \mathrm{sg}$ EMPH sleep-PST river on the other side

'I slept on the other side of the river'

(35) Bá ki daba-krá di' kába

2SG EMPH come-PST 1PL where

'You came to us (to our house)'

(36) I ki turi ramat ai'-kra bútkra túngkra rohk

3sG EMPH cow kill-PST bow arrow PL

édé

with

'He killed the cow with bow and arrow' 
Interrogative elements are placed at the beginning of the sentence (37) except for $i d e ́$ ? which is placed in final position (38), and though it has no specific translation, it has the function of emphasizing the interrogative quality of the phrase. Intonation also plays a role in interrogative sentences.
(37)

¿Dí-ra bá ki?
who-PRs you EMPH
'Who are you?'

$\begin{array}{llll}\text { (38) ¿I } & \text { shóhkrerá } & \text { ba-ng } & \text { dé? } \\ \text { how } & \text { (greeting) } & \text { you-EMPH } & \text { Q.EMPH }\end{array}$

'How are you?'

To summarize, the brief characterization provided above illustrates general aspects about the Boruca language. In future papers, a more thorough analysis will be made with the objective of presenting more information on each of the features of the language. Certainly, knowing more about Boruca will help us understand how the language functions. At the same time, this knowledge will contribute to a better understanding of the human languages and human thought in general.

\section{Abbreviations}

\begin{tabular}{|c|c|c|c|c|c|}
\hline ADJ & adjective & FUT & future & PST & past \\
\hline ART & article & GEN & genitive & Q & question marker \\
\hline $\mathrm{COP}$ & copula & IS & information- & QUANT & quantifier \\
\hline DAT & dative & & structure & REFL & reflexive \\
\hline DEF & definite & & marker & REL & relativizer \\
\hline DEM & demonstrative & NEG & negative & SG & singular \\
\hline DET & determiner & NUM & numeral & SPEC & specifier \\
\hline DIM & diminutive & PL & plural & SUBJ & subject \\
\hline EMPH & emphasis & POsS & possessive & TOP & topic \\
\hline FOC & focus & PRS & present & & \\
\hline
\end{tabular}

